\title{
Evaluation of surface characteristics of Ti-6AI-4V and Tilite alloys used for implant abutments
}

\section{Avaliação das características de superfície das ligas de Ti-6Al-4V e Tilite usadas para "abutments" de implantes}

\author{
Emilena Maria Castor Xisto Lima* \\ Wander José da Silva* \\ Juliana Silva Moura* \\ Fernanda Faot* \\ Altair Antoninha Del Bel Cury**
}

\begin{abstract}
The aim of this study was to evaluate surface free energy (SFE), surface roughness (SR) and surface hardness $(\mathrm{SH})$ of two commercially available materials for fabricating dental implant abutments. In addition, the specimens were investigated by scanning electron microscopy (SEM) to determine the surface morphology. Twenty five discs $(5 \times 2 \mathrm{~mm})$ of Ti-6Al-4V and Tilite (Ni-Cr-Ti) alloys were used in this study. Surface free energy was determined by the contact angle formed between a drop of distilled, deionized water and the surface of the specimen of each material. The surface roughness was measured with a mechanical profilometer and the surface hardness was evaluated by means of the Vickers hardness micro indentation test. SFE, SR and SH data were analyzed using one-way ANOVA $(\mathrm{p}<0.05)$. Statistical differences $(\mathrm{p}<0.05)$ were found between Ti-6Al-4V $\left(36.2 \mathrm{erg} . \mathrm{cm}^{-2} ; 0.2 \mu \mathrm{m}\right)$ and Tilite $\left(30.9\right.$ erg. $\left.\mathrm{cm}^{-2} ; 0.16 \mu \mathrm{m}\right)$ for SFE and SR. However, the differences between the surface hardness values of Ti-6Al-4V $\left(325.0 \mathrm{~kg} / \mathrm{mm}^{2}\right)$ and Tilite $\left(324.3 \mathrm{~kg} / \mathrm{mm}^{2}\right)$ were not statistically significant $(\mathrm{p}>0.05)$. Evaluations by SEM revealed different surface morphology. Within the limits of this study, it can be concluded that the Ti-6Al-4V and Tilite alloys showed differences in surface properties, except for surface hardness, suggesting that both alloys may be considered appropriate for producing abutments. Further studies are, however, necessary to elucidate the biological responses to implant abutments made with these alloys.
\end{abstract}

DESCRIPTORS: Surface properties; Dental implants; Titanium.

RESUMO: O objetivo deste estudo foi avaliar a energia livre de superficie (ELS), rugosidade superficial (RS) e dureza de superficie (DS) de dois materiais disponíveis comercialmente para fabricação de "abutments" de implante. Em acréscimo, os espécimes foram investigados por microscopia eletrônica de varredura (MEV) para determinar a morfologia de superficie. Vinte e cinco discos de ligas de Ti-6Al-4V e Tilite (Ni-Cr-Ti) $(5 \times 2 \mathrm{~mm})$ foram usados neste estudo. A energia livre de superfície foi determinada pela mensuração do ângulo de contato formado entre uma gota de água destilada e deionizada e a superficie do espécime para cada material. A rugosidade superficial foi mensurada com uso de um rugosimetro e a dureza de superficie foi avaliada por meio do teste de microdureza Vickers. Os dados foram analisados usando Análise de variância $(P<0,05)$. Foram encontradas diferenças significantes $(P<0,05)$ para os valores de ELS e RS entre Ti-6Al-4V (36,2 erg. $\left.\mathrm{cm}^{-2} ; 0,2 \mu \mathrm{m}\right)$ e Tilite $\left(30,9\right.$ erg. $\left.\mathrm{cm}^{-2} ; 0,16 \mu \mathrm{m}\right)$. Entretanto, os valores de dureza de superficie não foram diferentes para ambos os materiais (Ti-6Al-4V - 325,0 kg/mm² e Tilite - 324,3 kg/ $\left.\mathrm{mm}^{2}\right)(\mathrm{P}>0,05)$. A análise topográfica dos materiais pela MEV revelou superficies diferentes. Dentro das limitações deste estudo, concluiu-se que as ligas de Ti-6Al-4V e Tilite mostraram diferenças nas propriedades de superficies, exceto dureza, sugerindo que ambas as ligas são adequadas para a confecção de "abutments". Entretanto, estudos são necessários para evidenciar as respostas biológicas aos "abutments" de implantes confeccionados com essas ligas. DESCRITORES: Propriedades de superficie; Implantes dentários; Titânio.

\section{INTRODUCTION}

The surface properties of the implant and its prosthetic abutments ${ }^{8}$ provide one of the most important conditions relating to the future success of implant procedures. Since these components penetrate through the gingival mucosa and are also exposed to the oral cavity, they play an important role not only in biocompatibility but also in bacterial adhesion and stagnation. ${ }^{18}$

Biomaterial surface quality can be measured by a combination of physical, chemical and mechanical

\footnotetext{
* PhD Students; **Chair Professor - Department of Prosthodontics and Periodontology, School of Dentistry of Piracicaba, State University of Campinas.
} 
Lima EMCX, Silva WJ, Moura JS, Faot F, Cury AADB. Evaluation of surface characteristics of Ti-6Al-4V and Tilite alloys used for implant abutments. Braz Oral Res 2006;20(4):307-11.

properties and its surface structure. ${ }^{22}$ The adhesion of microorganisms to solid intraoral substrata involves interactions between their surface components, and is influenced by their hydrophobicity and surface free energy (SFE) values. ${ }^{15} \mathrm{SFE}$ has a significant impact on the adhesion process, since high SFE substrata attract more microorganisms than low energy materials, and bacterial adhesion appears to be weak on surfaces with a low SFE. ${ }^{15}$

As regards surface roughness (SR), some studies have reported a strong positive relationship between SR and the rate of supragingival bacteria. ${ }^{13,16,17}$ Moreover, SR interferes in biofilm formation and maturation, and increases the area available for adhesion by a factor of 2 to $3,{ }^{12,13,17}$ which may lead to severe problems with mucositis and peri-implantitis. ${ }^{22}$ Another important surface characteristic of implant components is surface hardness ( $\mathrm{SH})$, which may indicate the resistance to roughening during professional or habitual oral hygiene procedures. ${ }^{14}$

There are a large number of implant systems available, and most of them are made of titanium, due to its low toxicity and high biocompatibility. ${ }^{8}$ In addition to titanium, Tilite alloy (Ni-Cr-Ti) has recently been introduced as an alternative to materials available at present. Although there are no available data comparing surface characteristics of Tilite to those of Ti-6Al-4V, it has been stated that Tilite provides satisfactory marginal adaptation when used as superstructure for one-piece implant-supported dentures. ${ }^{6}$

Since there is a positive correlation between the surface characteristics of prosthetic implant components and plaque colonization, the aim of this study was to compare the surface characteristics and microstructures of two commercially available materials, Ti-6Al-4V and Tilite alloy (Ni-Cr-Ti), used to manufacture implant abutments.

\section{MATERIAL AND METHODS}

Twenty five specimens measuring $5 \mathrm{~mm}$ in diameter and $2 \mathrm{~mm}$ in thickness, made of Ti-6Al4V (Sandinox, São Paulo, SP, Brazil) and Tilite (composition: $76 \% \mathrm{Ni}, 13.5 \% \mathrm{Cr}, 6 \% \mathrm{Mo}, 4 \% \mathrm{Ti}$ ) (Talladium Inc., Valencia, CA, USA) were used in this study. The discs were kindly donated by their respective manufacturers and their surface finish was the same as that of commercial abutments. Surface free energy and surface roughness values were obtained without any additional polishing on the surface of the materials.
Surface free energy $\left(\mathrm{erg} \mathrm{cm}^{-2}\right)$ was determined with the deposition of $15 \mu \mathrm{l}$ of distilled water on each specimen. This was done in triplicate and an average was calculated. The image of each sessile drop was captured using a digital camera (Mavika CD 350, Sony, Tokyo, Japan) immediately after its deposition, and the mean value of contact angles was determined using Autocad 2005 (Auto Desk, Sankt Augustin, USA). ${ }^{11}$ Then, surface free energy was calculated using the cosine of the contact angles, in accordance with Minagi et al. ${ }^{11}$ (1985).

Surface roughness of the specimens was measured with a profilometer (Surfcorder SE 1700 Kozaka Industry, Kozaka, Tokyo, Japan) with a $0.01 \mu \mathrm{m}$ resolution, calibrated at a specimen length of $0.25 \mathrm{~mm}$, a $2.0 \mathrm{~mm}$ percussion of measure, and $0.5 \mathrm{~mm} / \mathrm{s}$. Six readings were made for each specimen and a mean value was calculated. These profilometric traces were taken from the edge, in the middle and at the bottom part of the specimen.

Surface hardness was measured by the Vickers microhardness indentation method (Shimadzu model HMV 2000, Kyoto, Tokyo, Japan). Since a shiny surface is required for measuring the indentations, specimens were ground with 320,400 and 600, 1,000 and 1,200-grit silicon carbide papers (Carbimet, Buehler, Lake Bluff, IL) in an Arotec APL-4 polishing machine (Arotec, São Paulo, SP, Brazil) under refrigeration, followed by polishing cloths and $3 \mu \mathrm{m}$ diamond suspension (Metadi diamond suspension, Buehler, Lake Bluff, IL). All discs were ultrasonically cleaned (Thornton T 740, Thornton-Inpec Eletrônica LTDA., Vinhedo, São Paulo, Brazil) for $10 \mathrm{~min}$ and dried. The Vickers hardness of each sample was calculated by means of three indentations made at a distance of $150 \mu \mathrm{m}$ between them, with a load of $50 \mathrm{~g}$ for $10 \mathrm{~s}$.

In addition, three discs of each alloy were used, as received from the manufacturers, for surface morphology evaluation, which was carried out with a scanning electron microscope (SEM; LEO 435 VP- Carl Zeiss SMT, Oberkochen, Germany). A $15 \mathrm{kV}$ beam energy was used. The images were analyzed at $500 \mathrm{X}$ and 1,500 X magnification.

\section{Statistical analysis}

All results were analyzed using statistical software (SAS version 9.0, SAS Institute Inc., Cary, NC, USA). Data underwent statistical analysis and the assumptions of homogeneity of variances and normal distribution of errors were tested for the response variables evaluated. Surface roughness values were transformed by square root. 
Lima EMCX, Silva WJ, Moura JS, Faot F, Cury AADB. Evaluation of surface characteristics of Ti-6Al-4V and Tilite alloys used for implant abutments. Braz Oral Res 2006;20(4):307-11.

Surface roughness, surface free energy and microhardness values were assessed using 1-way ANOVA considering the Tilite and Ti-6Al-4V groups. All analyses were performed at $\alpha=.05$.

\section{RESULTS}

Mean surface free energy, surface roughness and surface hardness values for each material are presented in Table 1. The SFE and SR of Ti-6Al$4 \mathrm{~V}$ were significantly higher $(\mathrm{p}<0.05)$ than that of Tilite. But no significant differences $(p>0.05)$ in surface hardness between the materials were found.

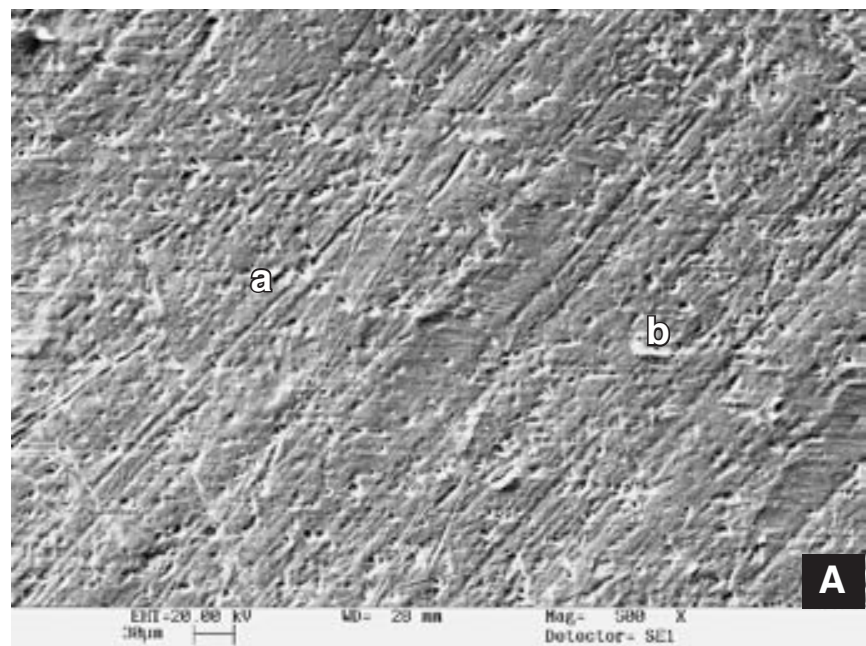

The SEM micrographs (Figures 1, A-B, and 2, A-B) revealed that the surface morphology of the materials are clearly distinct. Ti-6Al-4V showed a well-

TABLE 1 - Mean values and standard deviations $(\mathrm{n}=25)$ of surface free energy $\left(\mathrm{erg} . \mathrm{cm}^{-2}\right)$, surface roughness $(\mu \mathrm{m})$ and microhardness $\left(\right.$ Vickers $\mathrm{kg} / \mathrm{mm}^{2}$ ) for the Ti6Al-4V and Tilite alloys.

\begin{tabular}{l|c|c|c}
\hline \hline Materials & $\begin{array}{c}\text { Surface } \\
\text { free energy }\end{array}$ & $\begin{array}{c}\text { Surface } \\
\text { roughness }\end{array}$ & Microhardness \\
\hline Ti-6Al-4V & $36.2(3.9) \mathrm{a}$ & $0.20(0.05) \mathrm{a}$ & $325.0(10.1) \mathrm{a}$ \\
\hline Tilite & $30.9(3.5) \mathrm{b}$ & $0.16(0.03) \mathrm{b}$ & $324.3(14.9) \mathrm{a}$ \\
\hline \hline
\end{tabular}

Mean values followed by distinct letters differ significantly $(\mathrm{p}<0.05)$.

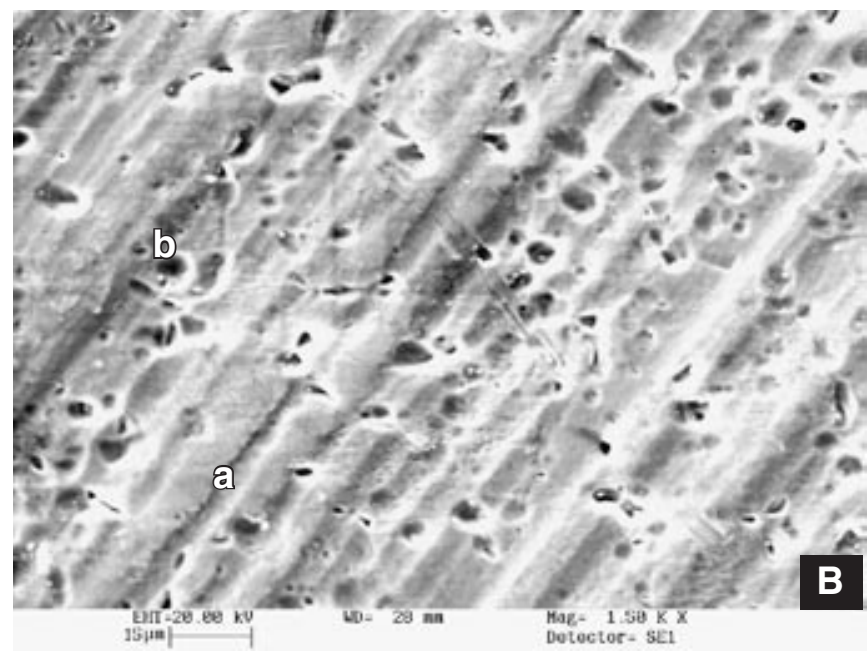

FIGURES 1, A-B - SEM of the Ti-6Al-4V alloy surface at $500 \mathrm{X}$ (A) and 1,500 X (B) magnification; well-defined unidirectional microstructure with irregular scratches and defects (a) and small pits (b) resulting from machining.
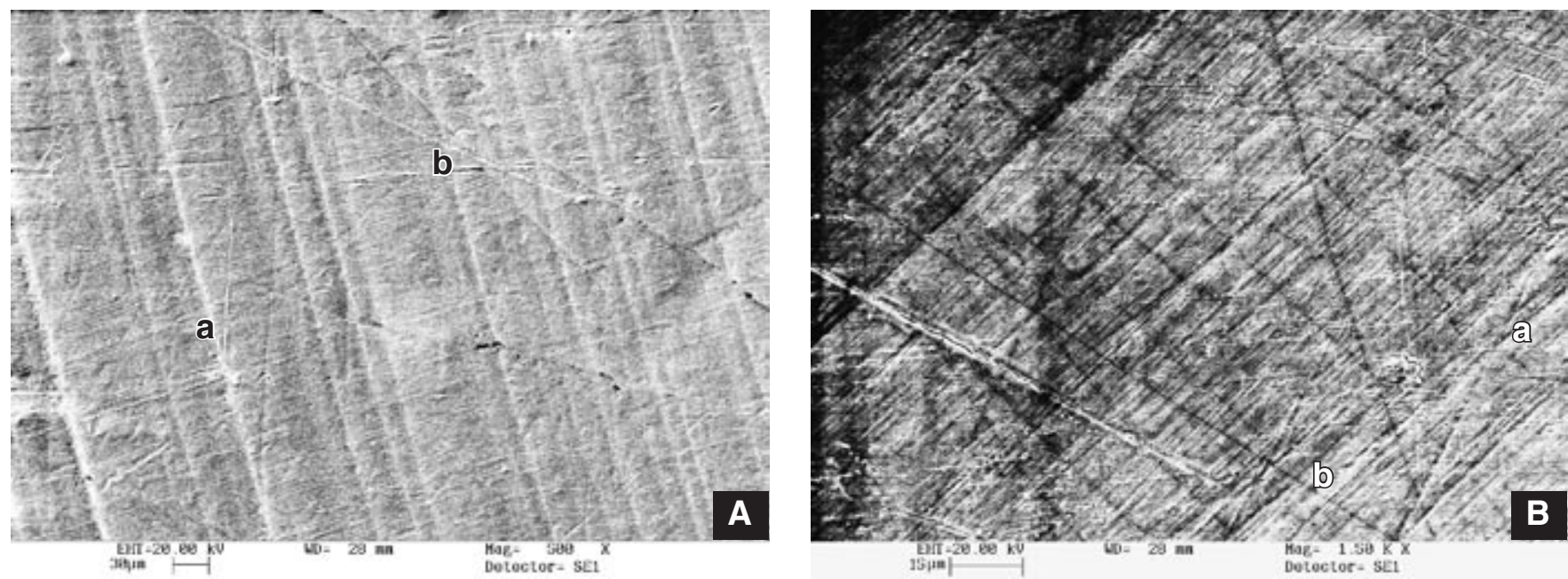

FIGURES 2, A-B - SEM of the Tilite alloy surface at 500 X (A) and 1,500 X (B) magnification; well-defined surface texture with an equally smooth surface and only minor irregularities (a) and light scratches (b) as a result of machining. 
Lima EMCX, Silva WJ, Moura JS, Faot F, Cury AADB. Evaluation of surface characteristics of Ti-6Al-4V and Tilite alloys used for implant abutments. Braz Oral Res 2006;20(4):307-11.

defined unidirectional microstructure with irregular scratches, small pits and turning marks (Figure 1, A-B) whereas Tilite (Figure 2, A-B) showed a well-defined surface texture with an equally smooth surface and only minor irregularities and light scratches.

\section{DISCUSSION}

The surface free energy of a solid surface gives a direct measurement of intermolecular interactions at interfaces and has a strong influence on wetting, adsorption and adhesion behavior. ${ }^{24} \mathrm{SFE}$ and wettability of materials can be determined by measuring the contact angle formed by a range of liquids on a given surface, using several different approaches. ${ }^{5,19}$ In the present study, Ti-6Al-4V had higher SFE compared with Tilite, meaning that the former has a greater potential for initial bacteria colonization. ${ }^{15}$ In this study, however, only distilled water with known surface tension $\left(72.8 \mathrm{erg} . \mathrm{cm}^{2}\right)$ was used for contact angle measurements, ${ }^{5}$ which could be a limitation for further discussions, since the polar and non-polar components of surface free energy were not determined.

Surface roughness has a major impact on microbial colonization. ${ }^{14}$ Preferential retention occurs on rough surfaces because on such surfaces bacteria are more protected against shear forces and oral hygiene measures, thus giving the entrapped microbial cells time to become irreversibly attached to the surface. ${ }^{12}$ Brecx et al. ${ }^{2}$ (1983) stated that the proliferation of the initially adhering microorganisms accounts for the major part of the microbial mass increase during early biofilm formation, which may explain the role of surface roughness in initial biofilm formation. ${ }^{1}$ The SR values found in this study were $0.16 \mu \mathrm{m}$ for the Tilite alloy and $0.2 \mu \mathrm{m}$ for Ti-6Al-4V (Table 1). These results are in accordance with the range found for commercially available implant components. ${ }^{18,22,23}$ Some in vivo studies suggested a threshold surface roughness for bacterial retention $(0.2 \mu \mathrm{m})$, below which no further reduction in bacterial accumulation could be expected. ${ }^{1}$ Thus, every dental material needs its own treatment modality in order to obtain and maintain a surface as smooth as possible.

SEM images showed different surface topographies between the materials (Figures 1, A-B, and 2, A-B). Based on the surface areas investigated, the density of the local defects (merely deviation from a uniform surface structure) appeared to be higher on the Ti-6Al-4V surface compared with the Tilite surface, but no quantitative analysis was performed.
According to information given by the manufacturers, Ti-6Al-4V is subjected to a chemical etching process, whereas Tilite does not receive any chemical treatment. Carlsson et al. ${ }^{3}$ (1988) and Carr et al. $^{4}$ (1997) stated that the use of an acid etch, such as that with hydrochloric acid, sulfuric acid and nitric acid, produced micro-cavities on the surface that varied according to the type, concentration and temperature of the acid, which may produce an unsuitable, rough surface and affect the resistance of the material. ${ }^{21}$

Surface hardness may explain the risk for surface roughening of the abutments of several implant systems during professional cleaning or even during habitual oral hygiene procedures. ${ }^{1,7}$ For $\mathrm{SH}$, there were no statistical differences between the Ti-6Al-4V and Tilite alloys (Table 1). The SH values found in this study are in agreement with those of Quirynen et al. ${ }^{14}$ (1994) who observed Vickers hardness values for abutments varying from 154 for Branemark to 340 for Steri-OSS.

With regard to professional cleaning, special care should be taken when ultrasonic scaling, metal instruments ${ }^{20}$ and air powder abrasive systems are used, because these methods lead to increased surface roughness. According to McCollum et al. ${ }^{9}$ (1992) only methods that do not damage the abutment surface or enhance biofilm accumulation should be used for maintenance and prophylaxis. Meschenmoser et al. ${ }^{10}$ (1996) stated that the instrument recommended for professional hygiene is the plastic curette. Although there are no studies about the influence of professional hygiene methods on surface roughness and structural modifications of implant abutments made of Tilite, because of the similarity in their surface hardness values, it probably presents the same behavior as that of Ti-6Al-4V.

\section{CONCLUSION}

Within the limits of this study, it can be concluded that the Ti-6Al-4V and Tilite alloys showed differences in surface characteristics, except for surface hardness. Further studies are, however, necessary to elucidate the biological responses to implant abutments made with these materials.

\section{ACKNOWLEDGEMENTS}

The authors wish to thank Neodent (Neodent, Curitiba, PR, Brazil) for providing the Ti-6Al-4V and Tilite discs used in this study. 
Lima EMCX, Silva WJ, Moura JS, Faot F, Cury AADB. Evaluation of surface characteristics of Ti-6Al-4V and Tilite alloys used for implant abutments. Braz Oral Res 2006;20(4):307-11.

\section{REFERENCES}

1. Bollen CM, Lambrechts P, Quirynen M. Comparison of surface roughness of oral hard materials to the threshold surface roughness for bacterial plaque retention: a review of the literature. Dent Mater. 1997;13(4):258-69.

2. Brecx M, Theilade J, Attstrom R. An ultrastructural quantitative study of the significance of microbial multiplication during early dental plaque growth. J Periodontal Res. 1983;18(2):177-86.

3. Carlsson L, Rostlund T, Albrektsson B, Albrektsson T. Implant fixation improved by close fit. Cylindrical implantbone interface studied in rabbits. Acta Orthop Scand. 1988;59(3):272-5.

4. Carr AB, Gerard DA, Larsen PE. Quantitative histomorphometric description of implant anchorage for three types of dental implants following 3 months of healing in baboons. Int J Oral Maxillofac Implants. 1997;12(6):777-84.

5. Combe EC, Owen BA, Hodges JS. A protocol for determining the surface free energy of dental materials. Dent Mater. 2004;20(3):262-8.

6. Costa HMF, Rodrigues RCS, Matos MGC, Ribeiro RF. Evaluation of the adaptation interface of one-piece implant-supported superstructures obtained in Ni-Cr-Ti and Pd-Ag alloys. Braz Dent J. 2003;14(3):197-202.

7. Fox SC, Moriarty JD, Kusy RP. The effects of scaling a titanium implant surface with metal and plastic instruments: an in vitro study. J Periodontol. 1990;61(8):485-90.

8. Kasemo B. Biocompatibility of titanium implants: surface science aspects. J Prosthet Dent. 1983;49(6):832-7.

9. McCollum J, O'Neal RB, Brennan WA, van Dyke TE, Horner JA. The effect of titanium implant abutment surface irregularities on plaque accumulation in vivo. J Periodontol. 1992;63(10):802-5.

10. Meschenmoser A, d'Hoedt B, Meyle J, Elssner G, Korn $\mathrm{D}, \mathrm{Hammerle} \mathrm{H}$ et al. Effects of various hygiene procedures on the surface characteristics of titanium abutments. $J$ Periodontol. 1996;67(3):229-35.

11. Minagi S, Miyake S, Inagaki K, Tsuru H, Suginaka H. Hydrophobic interaction in Candida albicans and Candida tropicalis adherence to various denture base resin materials. Infec Immun. 1985;47(1):11-4.

12. Nakazato G, Tsuchiya $H$, Sato $M$, Yamauchi M. In vivo plaque formation on implant materials. Int $\mathrm{J}$ Oral Maxillofac Implants. 1989;4(4):321-6.

13. Quirynen M, Bollen CM. The influence of surface roughness and surface-free energy on supra- and subgingival plaque formation in man. A review of the literature. $J$ Clin Periodontol. 1995;22(1):1-14.
14. Quirynen M, Bollen CM, Willems G, van Steenberghe D. Comparison of surface characteristics of six commercially pure titanium abutments. Int $\mathrm{J}$ Oral Maxillofac Implants. 1994;9(1):71-6.

15. Quirynen M, Marechal M, Busscher HJ, Weerkamp $\mathrm{AH}$, Arends J, Darius PL et al. The influence of surface free energy on planimetric plaque growth in man. J Dent Res. 1989;68(5):796-9.

16. Quirynen M, Marechal M, Busscher HJ, Weerkamp $\mathrm{AH}$, Darius PL, van Steenberghe D. The influence of surface free energy and surface roughness on early plaque formation. An in vivo study in man. J Clin Periodontol. 1990;17(3):138-4.

17. Quirynen M, van der Mei HC, Bollen CM, Schotte A, Marechal M, Doornbusch GL et al. An in vivo study of the influence of the surface roughness of implants on the microbiology of supra- and subgingival plaque. J Dent Res. 1993;72(9):1304-9.

18. Sawase T, Wennerberg A, Hallgren C, Albrektsson T, Baba K. Chemical and topographical surface analysis of five different implant abutments. Clin Oral Implants Res. 2000;11(1):44-50.

19. Sipahi C, Anil N, Bayramli E. The effect of acquired salivary pellicle on the surface free energy and wettability of different denture base materials. J Dent. 2001;29(3):197-204.

20. Speelman JA, Collaert B, Klinge B. Evaluation of different methods to clean titanium abutments. A scanning electron microscopic study. Clin Oral Implants Res. 1992;3(3):120-7.

21. Wennerberg A, Albrektsson T, Andersson B. Design and surface characteristics of 13 commercially available oral implant systems. Int $\mathrm{J}$ Oral Maxillofac Implants. 1993;8(6):622-33.

22. Wennerberg A, Albrektsson T, Andersson B, Krol JJ. A histomorphometric and removal torque study of screwshaped titanium implants with three different surface topographies. Clin Oral Implants Res. 1995;6(1):24-30.

23. Wennerberg A, Sennerby L, Kultje C, Lekholm U. Some soft tissue characteristics at implant abutments with different surface topography. A study in humans. J Clin Periodontol. 2003;30(1):88-94.

24. Zhao Q, Liu Y, Abel EW. Effect of temperature on the surface free energy of amorphous carbon films. J Colloid Interface Sci. 2004;280(1):174-83.

Received for publication on Apr 25, 2006 Sent for alterations on Jul 21, 2006 Accepted for publication on Aug 18, 2006 